\title{
Effects of structural and non-structural polysaccharides in the diet of the growing pig on gastric emptying rate and rate of passage of digesta to the terminal ileum and through the total gastrointestinal tract
}

\author{
BY Z. V. POTKINS ${ }^{1}$, T. L. J. LAWRENCE ${ }^{1}$ AND J. R. THOMLINSON ${ }^{2}$ \\ University of Liverpool, Departments of ${ }^{1}$ Animal Husbandry and ${ }^{2}$ Veterinary Pathology, \\ Veterinary Field Station, Neston, South Wirral L64 7TE
}

(Received 2 December 1989 - Accepted 20 September 1990)

\begin{abstract}
Six experiments were made in growing pigs to investigate the effects of substituting bran, oatmeal byproduct, pectin and guar gum for barley on gastric emptying rate, $\mathrm{pH}$ and dry matter of digesta and on the dry matter content and rate of passage of digesta to the terminal ileum and overall. Twelve pigs with cannulas sited at the pyloric/fundic junction of the stomach were used to measure gastric emptying. Seventy-two pigs were kept in metabolism cages for the total collection of faeces and nine pigs were fitted with simple cannulas $150 \mathrm{~mm}$ cranial to the ileo-caecal junction. For the overall transit measurements the barley was ground through a $4.68 \mathrm{~mm}$ screen $(C)$ and for the other studies either through this screen or a $1.56 \mathrm{~mm}$ screen (F). Gastric emptying rates were significantly faster for $F$ diets than for $C$ diets, but bran and oatmeal by-product substitutions were without significant effect on this variable or on rate of passage to the terminal ileum. Guar gum and pectin significantly speeded up gastric emptying and transit to the terminal ileum in $\mathrm{C}$ diets. Guar gum and pectin did not significantly affect overall transit time, but bran accelerated it. The results are discussed in relation to the depressive effects on nutrient utilization which have been recorded for the four polysaccharides: it is postulated that gastric emptying rate and transit time to the terminal ileum are likely to have a minimal effect on overall transit time.
\end{abstract}

Gastric emptying rate: Digesta passage rate: Dietary polysaccharides: Growing pig

Polysaccharides are composed of both structural (cellulose, hemicellulose and pectic substances) and non-structural (gums, mucilages and algal polysaccharides) types. Dietary fibre is usually a mixture of several of these polysaccharides which have different physicochemical properties and different physical characteristics, together with varying proportions of lignin. The aims of the experiments described in the present paper were to study the effects of dietary fibre on gastric emptying rate and rate of passage of digesta to the terminal ileum and through the total gastrointestinal tract, so that an understanding of its mode of action in affecting nutrient digestibility could be furthered.

The effects of dietary fibre on gastric emptying rate and rate of passage of digesta in the gastrointestinal tract are likely to be mediated by altering the volumes and physical properties of lumen contents. The emptying rate is also influenced by feedback control from the duodenum via receptors sensitive to the osmolality and acidity of digesta, and to other dietary factors including the particle size of the digesta (Laplace, 1982) which, in barleybased diets, can also affect gastric pH (Lawrence, 1970 b). Dietary fibre rich in structural polysaccharides as in bran, and soluble polysaccharides such as guar gum, have been shown to have some effects on gastric emptying rate at various points in time up to $4 \mathrm{~h}$ after feeding (Rainbird, 1986; Rainbird \& Low, 1986a,b): while there were some delays in 
emptying the digesta, none were found for dry matter. In the case of guar gum the retarding effects on gastric emptying found possibly reflect an increased viscosity affecting gastric motility (Rainbird \& Sissons, 1985).

The time-interval taken for digesta to pass to the terminal ileum is a function of the rate of release from the stomach and the speed of passage along the small intestine with the ileocaecal valve controlling the release of digesta into the large intestine (Laplace, 1981). Structural polysaccharides contained in lucerne (Medicago sativa) meal and in oat husk (Den Hartog et al. 1985), in bran and cellulose (solka floc) (Latymer et al. 1985), when added to cereal-based diets, have given equivocal results. So too have various soluble polysaccharides (Murray et al. 1977; Latymer et al. 1985). Bran has been found to depress apparent digestibility of nitrogen in the small intestine in some (Keys \& De Barthe, 1974a; Kass et al. $1980 a, b$; Graham et al. 1985) but not all (Livingstone, 1980) studies. Soluble polysaccharides such as guar gum have been found generally to be without significant effect on apparent digestibility (Huisman et al. 1985) although Murray et al. (1977) found that pectin and methyl cellulose significantly decreased the apparent digestibility of $\mathrm{N}$ and of protein-bound, but not free, lysine.

While bran and oatmeal by-products have been found to increase the overall rate of passage in non-cereal-based diets, their effects on cereal-based diets have not been consistent and generally very small (e.g. Canguilhem \& Labie, 1977; Latymer et al. 1985). Latymer et al. (1985) found that pectin and guar gum had no significant effect. Apparent digestibility of nutrients in diets in which bran, oatmeal by-product and other similar foodstuffs rich in structural polysaccharides have been substituted, has been decreased (Just et al. 1984). By contrast, pectin and guar gum appear to be without significant effect (Dierek et al. 1983; Huisman et al. 1985).

The aim of the study was to examine the effects of substituting bran, oatmeal by-product, pectin or guar gum in barley-based diets of two particle sizes on (1) pH and dry matter content of gastric digesta and rate of emptying and (2) dry matter content and rate of passage of digesta to the terminal ileum and through the total gastrointestinal tract.

\section{MATERIALS AND METHODS \\ Expt 1}

Aims. To study the effects of substituting bran (br) and oatmeal by-product (om) for barley in a barley-based diet on the rate of passage of digesta through the total gastrointestinal tract. A maximum concentration of $300 \mathrm{~g} / \mathrm{kg}$ of either foodstuff was chosen to avoid refusals. Five substitution levels were used, 0 (c diets), 75, 150, 225 and $300 \mathrm{~g}$ bran or oatmeal by-product/ $\mathrm{kg}$ diet to give diets $\mathrm{c}, 75 \mathrm{br}$ and $75 \mathrm{om}, 150 \mathrm{br}$ and $150 \mathrm{om}, 225 \mathrm{br}$ and $225 \mathrm{om}$ and diets $300 \mathrm{br}$ and $300 \mathrm{om}$ respectively. In addition barley (ba) only was given as a sixth treatment to compare the responses obtained from this cereal, which was progressively substituted in the five treatments for bran and oatmeal by-product, with those from the $\mathrm{c}$ diets in which ash and crude protein (nitrogen $\times 6.25$ ) contents were markedly higher (Table 1).

Diets. The compositions of the diets used are given in Table 1. The barley was ground through a $4.68 \mathrm{~mm}$ screen (C), typical of those used in practice, before being mixed with the other ingredients. Pigs were given daily $100 \mathrm{~g}$ air dry food $/ \mathrm{kg}$ metabolic live weight $\left(\mathrm{W}^{0 \cdot 75}\right)$ where the live weight was that recorded at the beginning of each of the two periods of the experiment (see p. 394). Half the daily allocation was given at 08.30 hours, the other half at 15.30 hours, each with water added (2.5 parts water:one part food) $15 \mathrm{~min}$ before feeding. The ingredients for each meal were weighed separately and all diets were mixed manually before and after the water had been added. 


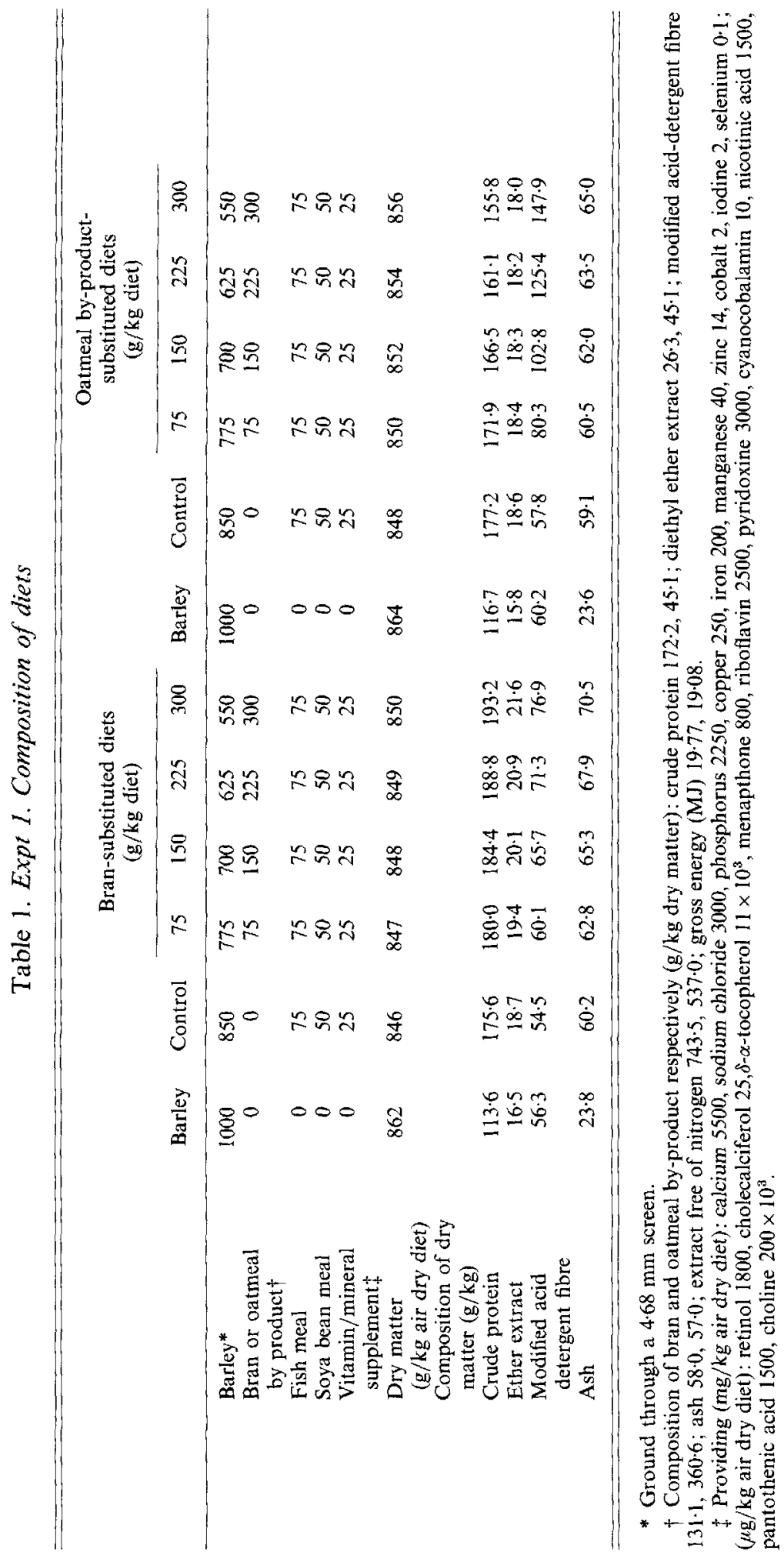


Experimental procedure. Six groups of six castrated male Large White litter-mates were used to compare different rates of substitution with bran. The same animals were used later to compare different rates of substitution with oatmeal by-product, but there was no intention to compare substitutions of bran with those of oatmeal by-product. All groups were first trained to live in metabolism cages situated in a room maintained at $23^{\circ}$. After this, the six pigs within each group were weighed to determine their food allowance, and were then allocated at random to the four diets containing the substituted bran, to the $c$ diet and to the ba diet. These diets were given for a period of $7 \mathrm{~d}$ before faeces collection started, commencing at 08.30 hours (morning feed) on day 1 . Collection continued for a further $5 \mathrm{~d}$, finishing at 08.30 hours on day 6. Pigs were then removed from their cages, weighed and, after a rest period of $3 \mathrm{~d}$, weighed again for the purpose of allocating food, before being returned to their cages. Then over a similarly-split 12-d period, in each group of six pigs the two pigs that were given diet $c$ and diet ba previously, were given the same food again. The four pigs that had previously received the four diets containing the substituted bran were given diets with oatmeal by-product substituted at the same concentrations. At 08.30 hours on day 6 the measurements were finished, and the pigs were removed from their cages and weighed. The means of the weights recorded on introducing and removing pigs from cages for each of the two experimental periods of $12 \mathrm{~d}$ were taken as the weights for pigs for those periods.

During each period of $5 \mathrm{~d}$ over which faeces were collected, studies were made on the rate of passage of the diets through the whole gut by incorporating chromic oxide (CR) as a marker at $10 \mathrm{~g} / \mathrm{kg}$ air-dry diet in the first feed ( 08.30 hours) on day 1 . For the purpose of measuring rate of passage, faeces were collected at half-hourly intervals from 15.00 hours to 22.30 hours on day 1 and from 07.00 hours to 22.30 hours on days 2 and 3 . Thereafter, on days 4 and 5 , faeces were collected at four-hourly intervals. Subsamples were taken from these faecal samples for CR determinations.

Analytical and statistical methods. Dry matter was measured in food and faeces samples by freeze-drying. CR concentration of each faecal sample was determined by the method of Christian \& Coup (1954), but using orthophosphoric acid instead of perchloric acid.

The cumulative excretion of CR $v$. time was plotted and the $5\left(t_{5}\right), 50\left(t_{50}\right)$ and $95\left(t_{95}\right) \%$ excretion times were taken from the smoothed sigmoid-shaped curves drawn through the points of this graph. To determine rate of passage, the values were transformed to enable a plot of the logarithm of CR voided in the faeces: CR remaining in the gut $(y) v$. the logarithm of time (hours after feeding: $x$ ), was made for each pig. The gradients of the central, linear portions $(m)$, which generally were between 5 and $95 \%$ excretion of $\mathrm{CR}$, were used to compare the rates of passage of the diets from the equation $y=m x+c$ (see Fig. 1). Using this approach, faster rates of passage of digesta were reflected in larger values for $m$ where $m$ and $c$ are constants.

Differences between diets were tested by analyses of variance appropriate to randomized block designs (GENSTAT; Lawes Agricultural Trust, 1982) and tests of significance between pairs of diets were based on the mean squares for diets $\times$ litters.

\section{Expt 2}

Aims. The effects of guar gum and pectin, substituted for barley in a barley-based diet, on rate of passage of digesta through the total gastrointestinal tract were measured. Substitution rates for barley in the control diet (c) (with the barley ground through a $4.68 \mathrm{~mm}$ screen as in Expt 1) of 10 and $50 \mathrm{~g}$ of either guar gum or pectin $/ \mathrm{kg}$ of diet, were used, giving diets 10 and $50 \mathrm{~g}$ and diets 10 and $50 \mathrm{p}$ respectively. These substitution rates were chosen semi-arbitrarily from a review of the literature, but with the knowledge that a concentration of $10 \mathrm{~g}$ pectin $/ \mathrm{kg}$ diet had been shown to affect the transit of digesta in the 


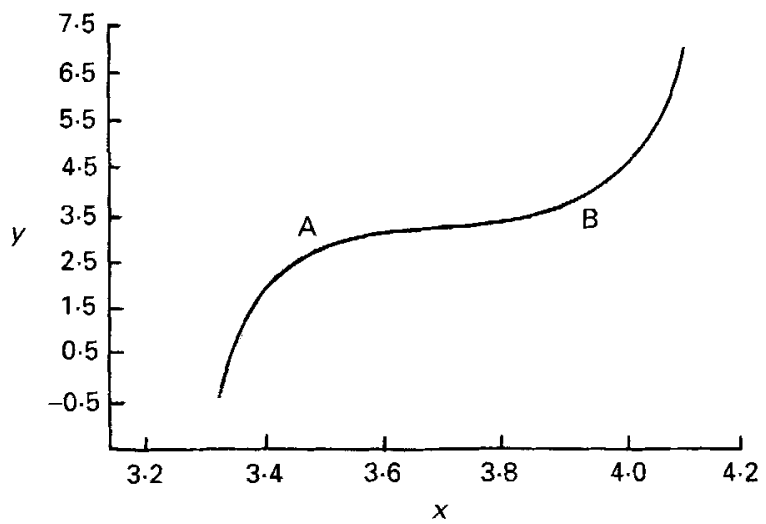

Fig. 1. Transformation of data to measure rate of passage of digesta through the total gut from the equation $y=m x+c$ applied to central linear part of sigmoid curve, between approximately points $\mathbf{A}$ and $\mathbf{B}$, where $y=\log$ of ratio $C R$ in faeces to $C R$ in gut, $x=\log$ of time (h) after feeding and $m$ and $c$ are constants.

Table 2. Expt. 2. Composition of diets

\begin{tabular}{|c|c|c|c|c|c|}
\hline & \multirow[b]{2}{*}{ Control } & \multicolumn{2}{|c|}{$\begin{array}{c}\text { Guar-gum-substituted } \\
\text { diets } \\
\text { (g/kg diet })\end{array}$} & \multicolumn{2}{|c|}{$\begin{array}{c}\text { Pectin-substituted } \\
\text { diets } \\
\text { (g/kg diet })\end{array}$} \\
\hline & & 10 & 50 & 10 & 50 \\
\hline Barley* & 850 & 840 & 800 & 840 & 800 \\
\hline Guar gum $\dagger$ & 0 & 10 & 50 & 0 & 0 \\
\hline Pectin + & 0 & 0 & 0 & 10 & 50 \\
\hline Fish meal & 75 & 75 & 75 & 75 & 75 \\
\hline Soya-bean meal & 50 & 50 & 50 & 50 & 50 \\
\hline Vitamin mineral supplement $\S$ & 25 & 25 & 25 & 25 & 25 \\
\hline Dry matter (g/kg air dry diet) & 843 & 843 & 845 & 843 & 847 \\
\hline \multicolumn{6}{|l|}{ Composition of dry matter $(\mathrm{g} / \mathrm{kg})$} \\
\hline Crude protein (nitrogen $\times 6.25$ ) & $177 \cdot 1$ & $176 \cdot 3$ & $173 \cdot 1$ & $175 \cdot 9$ & $171 \cdot 1$ \\
\hline Diethyl ether extract & $17 \cdot 4$ & $17 \cdot 3$ & $16 \cdot 8$ & $17 \cdot 3$ & $16 \cdot 7$ \\
\hline Modified acid detergent fibre & 57.5 & $57 \cdot 1$ & $55 \cdot 2$ & 56.9 & $54 \cdot 6$ \\
\hline Ash & $60 \cdot 9$ & $60 \cdot 7$ & $60 \cdot 0$ & 60.8 & $60 \cdot 4$ \\
\hline
\end{tabular}

* Ground through a $4.68 \mathrm{~mm}$ screen.

+ Meyhall Chemical Company, New Ferry, Merseyside; Meyprogat 150, MW 150, high viscosity; composition (g/ $\mathrm{kg}$ dry matter): crude protein $39 \cdot 4$, diethyl ether extract $3 \cdot 0$, modified acid detergent fibre $11 \cdot 6$, extract free of $\mathrm{N} 940 \cdot 8$, gross energy $17 \cdot 26 \mathrm{MJ}$.

¥ Hercules Powder Company, London; B150, high methoxyl, rapid set; composition (g/kg dry matter): crude protein $0 \cdot 0$, diethyl ether extract $2 \cdot 9$, modified acid detergent fibre $0 \cdot 0$, extract free of $\mathrm{N} 982 \cdot 7$, gross energy $16.9 \mathrm{MJ}$.

$\S$ Providing ( $\mathrm{mg} / \mathrm{kg}$ air dry diet): calcium 5500, sodium chloride 3000 , phosphorus 2250 , copper 250 , iron 200 , manganese 40 , zinc 14 , cobalt 2 , iodine 2 , selenium $01 ;(\mu \mathrm{g} / \mathrm{kg}$ air dry diet $)$ : retinol 1800 , cholecalciferol $25, \delta-\alpha-$ tocopherol $11 \times 10^{3}$, menapthone 800 , riboflavin 2500 , pyridoxine 3000 , cyanocobalamin 10 , nicotinic acid 1500 , pantothenic acid 1500 , choline $200 \times 10^{3}$.

rat (Gohl \& Gohl, 1977), and that Murray et al. (1977) had shown some effect on protein digestion when gel-forming complex polysaccharides were included at concentrations of $60 \mathrm{~g} / \mathrm{kg}$ diet. Pigs were used for one experimental period only because of suggestions that in rats and chicks, the effects of guar gum and pectin on the gastrointestinal tract could last for several weeks after their inclusion in the diet had ended (Gohl \& Gohl, 1977; Gohl et al. 1978). 
Diets and experimental procedure. The design of the experiment was a randomized block using six groups of six litter-mate castrated male pigs. The diets (Table 2) were randomly allocated to the pigs in each litter. The experimental routine and the analyses were identical to those used in Expt 1 except that diets were given to one group of pigs for one period only. The guar gum and pectin were mixed as powders with the other dietary ingredients and the only hydration was that which occurred 15 min before feeding.

\section{Expt 3}

Aims. The effects on gastric emptying rate and on the $\mathrm{pH}$ and dry matter of gastric digesta, of diets identical in composition to the control diet (Cc) and the diets containing $225 \mathrm{~g} / \mathrm{kg}$ of substituted bran and oatmeal by-product used in Expt 1 (diets $\mathrm{Cbr}$ and Com respectively) were measured. Three other diets were compared with these, identical in composition but with the barley ground through a $1.56 \mathrm{~mm}$ screen $(F)$ to produce barley particle sizes which, for various reasons, often form bases of diets in practice and cause problems; these diets were designated Fc, Fbr and Fom. The comparison of the C- and Fbased diets was chosen because previous work had shown significant differences in effects on gastric $\mathrm{pH}$ and nutrient utilization (Lawrence, $1970 a, b$ ). The substitution levels of $225 \mathrm{~g} / \mathrm{kg}$ were chosen because, at the time the experiment started, preliminary results from Expt 1 had indicated that, with this level of replacement of barley, rate of passage of digesta through the total gut was significantly altered.

Cannulation of the stomach. Eight castrated male pigs weighing about $25 \mathrm{~kg}$ live weight were trained to live in metabolism cages situated in a room where the temperature was maintained at $23^{\circ}$. When about $40 \mathrm{~kg}$ live weight, they were fitted with cannulas made from a deldrin acetyl rod (G. Bloore and Sons, Manchester), the stems of which had internal diameters and lengths of 35 and $50 \mathrm{~mm}$ respectively, with base plates of $90 \mathrm{~mm}$ diameter. The cannulas were fitted with rubber bungs and were sited at the pyloric-fundic junction using a method based on that of Abel \& Buck (1967); full details and post-operative care are described by Potkins (1986).

Experimental design and routine. After recovery periods of up to 3 weeks the pigs were randomized among the diets in an experiment of cross-over design in which each pig received each of the six diets in a random order. Each diet was given for 14 consecutive days, the first $9 \mathrm{~d}$ being an adaptation period and the following $5 \mathrm{~d}$ an experimental period. At the beginning of each adaptation period each pig was weighed and food adjusted to $100 \mathrm{~g}$ air dry matter $/ \mathrm{kg} \mathrm{W}^{0.75}$. Diets were given twice daily in two equal portions at 08.30 and 16.00 hours. Water was added to the food in the ratio 2.5 parts water: one part food, $15 \mathrm{~min}$ before feeding.

Emptying the stomach. During experimental periods the stomach of each pig was emptied on any one day at $0.5,1,2,4$ or $7.5 \mathrm{~h}$ after the morning feed. For each pig the digesta was collected at a different time each collection day and at times of collection that were as different as possible on collection days 1,3 and 5. Most food was consumed within 10 min but some pigs required longer, up to $20 \mathrm{~min}$, to eat the diets containing bran.

To empty the stomach the rubber bung was removed from the cannula and any digesta in the neck was removed and retained separate from the other digesta. If the digesta in the stomach were fluid, they flowed freely into the collection vessel held beneath the open mouth of the cannula. If the flow was not spontaneous, or after the spontaneous flow had ceased, as much digesta as possible was removed from the stomach using a small plastic spoon. The remaining digesta were removed by pouring up to 1 litre water into the stomach using a funnel and tubing (introduced through a rubber bung), removing the bung and collecting the washings separately from the previous sample. The washing procedure was repeated until the washings were free of solid matter. 


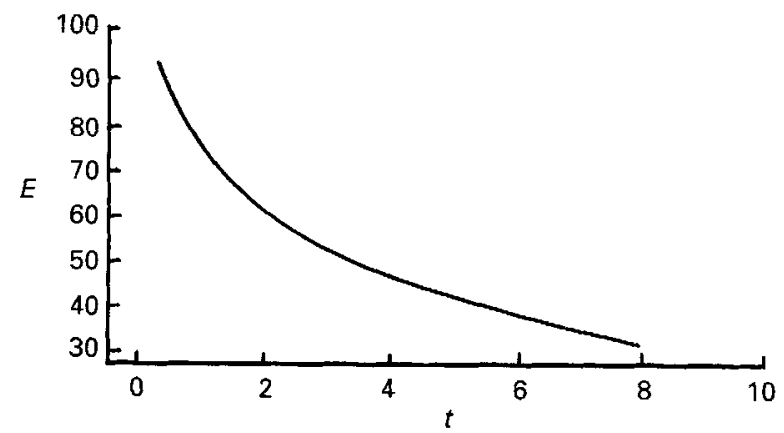

Fig. 2. Measurement of gastric emptying rate from transformation of curve to $\log E=k+k_{\mathrm{s}} t$ where $E=$ ratio of dry matter in stomach $(\mathrm{g})$ to dry matter intake in one meal $(\mathrm{g}), t=$ time between previous meal and the emptying of the stomach $(\mathrm{h})$ and $k_{\mathrm{s}}=$ gradient of the straight line (rate constant).

The digesta (excluding the initial plug and the washings) were weighed and their $\mathrm{pH}$ and dry matter content determined. The washings and the plug of digesta first removed were weighed and their dry matter determined separately to enable the total dry matter content of the digesta to be calculated.

When all the digesta had been removed, as indicated when the washings were free of solid matter, the bung was replaced and the animal was given an amount of the same diet judged to be equal to that which had been removed in the digesta.

Analysis of results. The decrease in the total dry matter in the stomach was calculated as the ratio $(E)$ :

$$
\frac{\text { total dry matter in the stomach }(\mathrm{g})}{\text { total dry matter given in one meal }(\mathrm{g})}
$$

over the period of time of $7.5 \mathrm{~h}$ after feeding for each pig. This gave an exponential decay curve (Fig. 2) and the data were then transformed to a semi-logarithmic base to produce a straight line of the form.

$$
\log E=k+k_{\mathrm{s}} t
$$

where $E$ is the ratio given above, $t$ is time between the previous meal and the emptying of the stomach (h), $k$ is a constant and $k_{\mathrm{s}}$ is the gradient of the straight line (the rate constant). Values of $k_{\mathrm{s}}$ were then used to compare emptying rates for each treatment by analysis of variance. This was considered the preferred method of measuring gastric emptying rates rather than simply taking the mean time for half the dry matter to empty from the stomach (the $t_{50}$ time), a measure which could be significantly influenced by a reduction in emptying seen $4 \mathrm{~h}$ after feeding as in the work of Rainbird \& Low (1986a).

Values for dry matter and for $\mathrm{pH}$ appeared to follow no particular trend and therefore were not suited to any mathematical transformation. Therefore, results for each collection time were compared by analyses of variance using a simple randomized-block design with the pig $\times$ diet interaction mean square used as the error term.

\section{Expt 4}

Aims. The effects were measured on the same variables as in Expt 3 of diets $\mathrm{Cc}$ and $\mathrm{Fc}$, as used in that experiment, and diets in which $50 \mathrm{~g} / \mathrm{kg}$ (one of the substitution levels used in Expt 2 (see Table 2)) of either guar gum or pectin had been substituted for barley. With the $\mathrm{C}$ and $\mathrm{F}$ barley bases there were, therefore, six diets: $\mathrm{Fc}, \mathrm{Cc}, \mathrm{Fg}, \mathrm{Cg}, \mathrm{Fp}$ and $\mathrm{Cp}$. The substitution level of $50 \mathrm{~g} / \mathrm{kg}$ was chosen semi-arbitrarily but with the knowledge that the substitution of $60 \mathrm{~g} / \mathrm{kg}$ in a semi-purified diet had retarded gastric emptying time at $1 \mathrm{~h}$ and $4 \mathrm{~h}$ after feeding (Rainbird \& Low, 1986 b). 
Experimental design, routine and analyses. Four pigs were fitted with gastric cannulas as in Expt 3, and were given the six diets in an experiment of cross-over design so that each pig received each of the six diets in a random order. All other aspects of the experiment were as for Expt 3, and as in Expt 2 there was no hydration of the guar gum and pectin other than that which occurred 15 min before feeding.

\section{Expt 5}

Aims. Relative to Expts 1, 2, 3 and 4, the terminal ileum was considered as an appropriate point at which to study further the effects of fibre in the diet on the transit rate of digesta. Digestion of nutrients effected to the terminal ileum could be affected by the rate of passage of digesta to this point and this, in turn, could be affected by gastric emptying rate. Thus transit of diets with substitutions of bran and oatmeal by-product for barley, at concentrations of $225 \mathrm{~g} / \mathrm{kg}$ diet as in Expts 1 and 3, were made.

Cannulation of the terminal ileum. Six castrated male pigs were fitted with simple plastic cannulas, $18 \mathrm{~mm}$ internal diameter, in the terminal ileum $150 \mathrm{~mm}$ from the ileo-caecal junction. Surgery and post-operative care were as described by Rowan (1983) and experimental work was not carried out until at least $14 \mathrm{~d}$ after the operation.

Experimental design and routine. The barley was of the C-type used in previous experiments and was chosen in preference to an F-type barley because of (1) limitations in the number of treatments which could be studied with the experimental design, (2) it was nearer to the particle size of barley which is used commonly in practical pig feeding and (3) from the literature there were no indications of different particle sizes affecting digesta transit time in the small intestine.

The experimental design intended and initiated was a two-replicate, $3 \times 3$ Latin square, but due to the refusal of some pigs to eat the diet containing bran, and to blockages at the site of the cannula resulting in its displacement and a consequential inability to collect digesta, the design had to be changed to one in which comparisons of diet $\mathrm{Cc}$ with $(a)$ diet $\mathrm{Cbr}$ and $(b)$ diet Com were possible in four pigs only in each case, with only two pigs being common to both comparisons. As the initial Latin square-designed experiment had been started the resulting allocation of pigs to any two diets other than that which they had started on, was at random.

Each pig was weighed at the beginning of the experimental period and the food allowance adjusted to give $100 \mathrm{~g}$ food $/ \mathrm{kg} \mathrm{W}^{0.75}$ given in two equal portions at 08.30 and 15.30 hours and mixed with water as in previous experiments. At $3 \mathrm{~d}$ before the collection of digesta commenced, and 2-3 d after introducing a diet, pigs were moved to metabolism cages to which they had been trained before surgery. Feeding of this diet was then continued for $6 \mathrm{~d}$ before collection of digesta samples commenced. To determine rate of passage of digesta, $\mathrm{CR}$ at a dietary concentration of $10 \mathrm{~g} / \mathrm{kg}$ air-dry matter was used as a marker. This amount of $\mathrm{CR}$ was incorporated in the food given at the morning $(08.30$ hours) feed of the seventh day. Digesta were removed from collection bags attached to the cannulas at hourly intervals between 11.00 and 22.00 hours on the first day and at threehourly intervals from 07.00 and 20.00 hours on the following day. At all times frequent checks were made for blockages. The following morning the pigs were taken out of their cages, weighed, the diets changed and the amounts of food recalculated using the new live weight. Samples were immediately stored at $-20^{\circ}$, and before analysis for CR they were freeze-dried to determine dry matter concentrations. The concentration of $C R$ in the dry matter of each sample collected was determined as in Expts 1 and 2.

Analysis of results. Rate constants, as expressions of rates of passage of digesta, were calculated for comparing differences between diets $\mathrm{Cc}$ and $\mathrm{Cbr}$ and between diets $\mathrm{Cc}$ and Com, using paired $t$ tests each based on four pigs. CR concentrations in digesta dry matter 


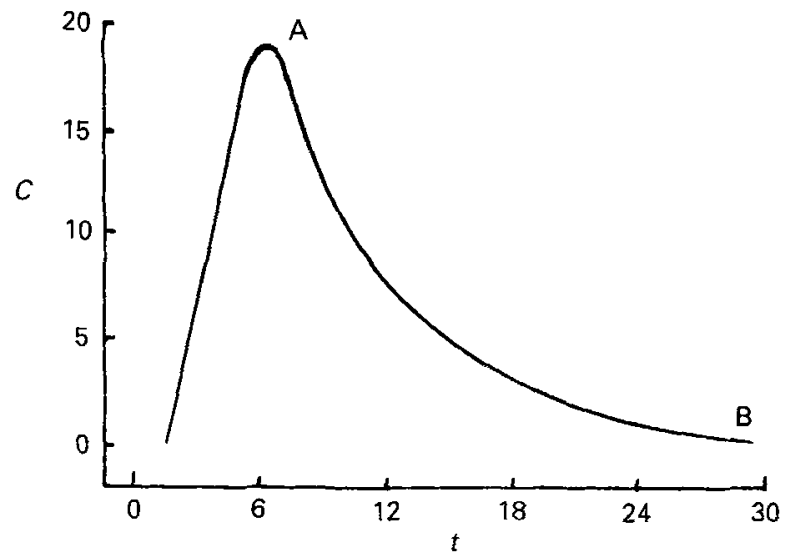

Fig. 3. Measurement of rate of passage of digesta to terminal ileum from transformation of curve between maximum concentration of $\mathrm{CR}$ to last sample, approximately between $\mathrm{A}$ and $\mathrm{B}$, to $\log C_{i}=a+k_{i} t$ where $C=$ concentration of $\mathrm{CR}$ in the sample ( $\mathrm{mg} / \mathrm{kg}$ dry matter), $t=$ time after the meal containing the CR had been given $(h)$ and $k_{i}=$ gradient of the straight line.

peaked at about $18.5 \mathrm{mg} / \mathrm{kg}$ about $6.5 \mathrm{~h}$ after feeding and then decreased exponentially to near zero levels $24 \mathrm{~h}$ after feeding (Fig. 3). To determine rate constants CR concentrations were transformed to a logarithmic base and, from the point of maximum concentration to the last sample, were plotted against time to give a linear relationship following first-order kinetics as described by the equation

$$
\log C_{i}=a+k_{i} t
$$

where $C_{i}$ is the concentration (mg/kg dry matter) of CR in the sample, $t$ is time (h) after the food containing the CR had been given, $a$ is constant and $k_{i}$ is the gradient of the straight line (rate constant).

\section{Expt 6}

Aims. To investigate the effects of substituting guar gum and pectin for barley in the diet at $50 \mathrm{~g} / \mathrm{kg}$, the concentration used in Expt 4, on the transit time of digesta to the terminal ileum.

Experimental design and routine. The experiment was carried out in a similar manner to Expt 5. Diets were again based on coarsely-ground (C) barley and the three diets $(\mathrm{Cc}, \mathrm{Cg}$ and $\mathrm{Cp}$ ) given were those used in Expt 4. Three pigs were each fitted with a cannula in the terminal ileum and the three diets were given in a $3 \times 3$ Latin square-designed experiment.

Analysis of results. Analyses of variance were used for all values with 2 degrees of freedom for the error mean square.

\section{RESULTS}

\section{Expt 1. Bran substitution}

The results are given in Table 3 . Diets $\mathrm{c}$ and 75 br gave faeces of the highest dry matter contents and diets 225 br and 300 br gave faeces of the lowest dry matter contents. With the exception of pigs given diet $225 \mathrm{br}$, the dry matter content of the faeces from pigs given diet 300 br was significantly less than that for the faeces from the pigs given the other diets $(P<0.05)$. Also with the exception of pigs given diet $75 \mathrm{br}$, the dry matter content of the faeces from pigs given diet $\mathrm{c}$ was significantly greater than that from the pigs given the other diets $(P<0.05)$.

There were no significant differences between the $t_{5}$ times of CR. Diet ba had significantly greater $t_{50}$ and $t_{95}$ times than diets 150,225 and $300 \mathrm{br}(P<0.01)$ and a significantly greater 
Table 3. Expt 1. Effect of dietary bran substitution on dry matter content of faeces and rate of passage of digesta through total gastrointestinal tract in pigs

\begin{tabular}{|c|c|c|c|c|c|c|c|c|}
\hline \multirow[b]{2}{*}{ Dietary treatment* } & \multirow[b]{2}{*}{ Barley } & \multirow[b]{2}{*}{ Control } & \multicolumn{4}{|c|}{$\begin{array}{c}\text { Bran substitution diets } \\
\text { ( } \mathrm{g} / \mathrm{kg} \text { diet })\end{array}$} & \multirow{2}{*}{$\begin{array}{l}\text { SED } \\
25 \mathrm{df}\end{array}$} & \multirow{2}{*}{$\begin{array}{c}\text { Statistical } \\
\text { significance } \\
\text { of difference } \\
P<\dagger\end{array}$} \\
\hline & & & 75 & 150 & 225 & 300 & & \\
\hline No. of pigs & 6 & 6 & 6 & 6 & 6 & 6 & & \\
\hline \multicolumn{9}{|l|}{ Live wt of pigs $(\mathrm{kg})$} \\
\hline Mean & $21 \cdot 2$ & $19 \cdot 5$ & $20 \cdot 9$ & $20 \cdot 5$ & $21 \cdot 4$ & $20 \cdot 9$ & & \\
\hline $\mathrm{SE}$ & $1 \cdot 1$ & 1.9 & $1 \cdot 6$ & $1 \cdot 2$ & 1.7 & $1 \cdot 1$ & & \\
\hline $\begin{array}{l}\text { Dry matter content of faeces } \\
(\mathrm{g} / \mathrm{kg})\end{array}$ & 273 & 310 & 292 & 280 & 250 & 248 & $10 \cdot 5$ & 0.01 \\
\hline \multicolumn{9}{|l|}{ Rate of passage } \\
\hline \multicolumn{9}{|l|}{$\begin{array}{l}\text { Excretion of chromic oxide } \\
\text { (CR) (h) }\end{array}$} \\
\hline $\begin{array}{l}t_{5} \text { excretion time }(\mathrm{h}) \\
(5 \% \text { excretion of } \mathrm{CR})\end{array}$ & $20 \cdot 4$ & $19 \cdot 3$ & $18 \cdot 2$ & $21 \cdot 1$ & $16 \cdot 5$ & $17 \cdot 0$ & 3.01 & \\
\hline $\begin{array}{l}t_{50} \text { excretion time }(\mathrm{h}) \\
(50 \% \text { excretion of } \mathrm{CR})\end{array}$ & $34 \cdot 0$ & $29 \cdot 9$ & $29 \cdot 6$ & $28 \cdot 0$ & $26 \cdot 1$ & $24 \cdot 8$ & $2 \cdot 06$ & 0.01 \\
\hline $\begin{array}{l}t_{95} \text { excretion time }(\mathrm{h}) \\
(95 \% \text { excretion of } \mathrm{CR})\end{array}$ & $56 \cdot 9$ & $48 \cdot 9$ & $51 \cdot 3$ & $45 \cdot 8$ & $43 \cdot 0$ & $41 \cdot 9$ & $2 \cdot 83$ & 0.05 \\
\hline$m \ddagger$ & 4.81 & $5 \cdot 19$ & $4 \cdot 32$ & $6 \cdot 31$ & 5.09 & $8 \cdot 36$ & 1.042 & 0.05 \\
\hline
\end{tabular}

SED, standard error of difference.

* For details, see Table 1 and p. 392.

$\dagger$ Overall test for differences between diets $P>0.05$ unless otherwise stated.

+ From equation $y=m x+c$, where $y$ is the logarithm of CR in the faeces: CR in the total gastrointestinal tract, $x$ is the logarithm of time (h) after feeding and $m$ and $c$ are constants.

$t_{95}$ time than diet $\mathrm{c}$. The $t_{95}$ value for diet $75 \mathrm{br}$ was significantly greater than that for diet $225 \mathrm{br}$. The diet containing the greatest concentration of bran (diet $300 \mathrm{br}$ ) gave a significantly greater value for $m$, indicating an increased rate of passage, compared with all diets $(P<0.05)$ except diet $150 \mathrm{br}$. The values for all other diets, including $150 \mathrm{br}$, were not significantly different from each other.

\section{Expt 1. Oatmeal by-product substitution}

Dry matter contents of the faeces are given in Table 4. The dry matter content of the faeces was generally greater for increasing concentrations of om in the diet. The dry matter content of the faeces of pigs consuming diet ba was lowest and significantly different from that of the other diets $(P<0.05)$. The values for diets 150,225 and 300 om were not significantly different from each other. Also diets c and $75 \mathrm{om}$ did not differ significantly from each other $(P>0.05)$.

Although rates of passage tended to increase with increasing oatmeal by-product substitution, there were no significant differences for $m$ or $t_{5}$. The mean values for $t_{50}$ and $t_{95}$ for diets $\mathrm{c}$ and ba were greater than for all other diets, and significantly greater than diets 225 and 300 om $(P<0.05$ and $P<0.01$ respectively).

\section{Expt 2}

The results are given in Table 5. Differences between the pectin and guar gum substitutions did not significantly affect faecal dry matter content. The dry matter content of the faeces of pigs given diet ba was significantly lower than that of pigs given diets $\mathrm{c}$ or $50 \mathrm{~g}$, and that of pigs given diet $50 \mathrm{~g}$ significantly higher than for diets ba or $50 \mathrm{p}(P<0.05)$.

There were no significant differences in any of the rate of passage variables measured. 
Table 4. Expt 1. Effect of dietary oatmeal by-product substitution on dry matter content of faeces and rate of passage of digesta through total gastrointestinal tract in pigs

\begin{tabular}{|c|c|c|c|c|c|c|c|c|}
\hline \multirow[b]{2}{*}{ Dietary treatment* } & \multirow[b]{2}{*}{ Barley } & \multirow[b]{2}{*}{ Control } & \multicolumn{4}{|c|}{$\begin{array}{l}\text { Oatmeal by-product } \\
\text { substitution }(\mathrm{g} / \mathrm{kg} \text { diet })\end{array}$} & \multirow{2}{*}{$\begin{array}{l}\text { SED } \\
25 \mathrm{df}\end{array}$} & \multirow{2}{*}{$\begin{array}{c}\text { Statistical } \\
\text { significance } \\
\text { of difference: } \\
P<\dagger\end{array}$} \\
\hline & & & 75 & 150 & 225 & 300 & & \\
\hline No. of pigs & 6 & 6 & 6 & 6 & 6 & 6 & & \\
\hline \multicolumn{9}{|l|}{ Live wt of pigs $(\mathrm{kg})$} \\
\hline Mean & $24 \cdot 2$ & $25 \cdot 3$ & $25 \cdot 9$ & $25 \cdot 8$ & $26 \cdot 1$ & $26 \cdot 7$ & & \\
\hline $\mathrm{SE}$ & $1 \cdot 1$ & $2 \cdot 8$ & $2 \cdot 0$ & 1.6 & 1.8 & 1.0 & & \\
\hline $\begin{array}{l}\text { Dry matter content of faeces } \\
(\mathrm{g} / \mathrm{kg})\end{array}$ & 283 & 322 & 341 & 364 & 360 & 372 & $11 \cdot 4$ & $0 \cdot 001$ \\
\hline \multicolumn{9}{|l|}{ Rate of passage } \\
\hline \multicolumn{9}{|l|}{$\begin{array}{l}\text { Excretion of chromic oxide } \\
\text { (CR) (h) }\end{array}$} \\
\hline $\begin{array}{l}t_{5} \text { excretion time }(\mathrm{h}) \\
(5 \% \text { excretion of } \mathrm{CR})\end{array}$ & $20 \cdot 8$ & $26 \cdot 3$ & $23 \cdot 3$ & $23 \cdot 8$ & $22 \cdot 3$ & $20 \cdot 4$ & $2 \cdot 90$ & \\
\hline $\begin{array}{l}t_{50} \text { excretion time (h) } \\
(50 \% \text { excretion of CR) }\end{array}$ & $37 \cdot 9$ & $38 \cdot 5$ & $34 \cdot 1$ & $34 \cdot 9$ & $28 \cdot 6$ & $29 \cdot 1$ & $3 \cdot 28$ & 0.05 \\
\hline $\begin{array}{l}t_{95} \text { excretion time }(\mathrm{h}) \\
(95 \% \text { excretion of } \mathrm{CR})\end{array}$ & $62 \cdot 8$ & $63 \cdot 1$ & $56 \cdot 1$ & $54 \cdot 1$ & $48 \cdot 0$ & $48 \cdot 3$ & 4.02 & 0.01 \\
\hline$m *$ & 488 & 5.44 & $5 \cdot 33$ & 4.59 & $5 \cdot 56$ & $6 \cdot 25$ & 0.624 & \\
\hline
\end{tabular}

SED, standard error of difference.

* For details, see Table 1 and p. 392.

$\uparrow$ Overall test for differences between diets $P>0.05$ unless otherwise stated.

$\mp$ From equation $y=m x+c$, where $y$ is the logarithm CR in the faeces: CR in the total gastrointestinal tract, $x$ is the logarithm of time (h) after feeding and $m$ and $c$ are constants.

\section{Expt 3}

Mean gastric emptying rates, $\mathrm{pH}$ and gastric dry matter content values are given in Table 6.

The emptying rate of the $\mathrm{F}$ diets was significantly faster than the $\mathrm{C}$ diets $(P<0.001)$. There were no significant differences, compared with diet $c(P>0.05)$ in emptying rate from substituting for barley, bran or oatmeal by-product.

There were no significant differences in digesta $\mathrm{pH}$ between the diets at 2 or $4 \mathrm{~h}$ after food had been given $(P>0.05)$. After $1 \mathrm{~h}$ the $\mathrm{pH}$ of the digesta of the pigs given the $\mathrm{F}$ diets was significantly greater than that of the pigs given the $\mathrm{C}$ diets $(P<0.05)$ but at $7.5 \mathrm{~h}$ the $\mathrm{pH}$ of the digesta from the $\mathrm{F}$ diets was significantly less than that from the $\mathrm{C}$ diets $(P<0.01)$. At 1 and $7.5 \mathrm{~h}$ there were no significant differences between the diets containing bran or oatmeal by-product on the one hand and the c diets on the other hand.

Comparison of the individual mean $\mathrm{pH}$ values after $0.5 \mathrm{~h}$ showed, with the exception of the diets containing oatmeal by-product, all diets to be statistically significantly different from each other $(P<0.05)$.

At $0.5 \mathrm{~h}$ the dry matter content of the digesta of the pigs given diets Com and Fc was significantly lower than that of those given diet $\mathrm{Cc}(P<0.05)$. After $1 \mathrm{~h}$ the dry matter content of the digesta from diet $\mathrm{Cc}$ was significantly greater than those of all other diets $(P<0.05)$, and at $2 \mathrm{~h}$ that of diet $\mathrm{Fc}$ was significantly less than those for all other diets $(P<0.05)$. At $2 \mathrm{~h}$ the dry matter content of digesta tended to be lower for the $\mathrm{F}$ diets compared with the $\mathrm{C}$ diets and at $4 \mathrm{~h}$ and $7.5 \mathrm{~h}$ this difference was statistically significant ( $P<0.01$ and $P<0.001$ respectively). There were no statistically-significant differences 
Table 5. Expt 2. Effect of dietary guar gum and pectin substitution on dry matter content of faeces and rate of passage of digesta through total gastrointestinal tract in pigs

\begin{tabular}{|c|c|c|c|c|c|c|c|c|}
\hline \multirow[b]{2}{*}{ Dietary treatment* } & \multirow[b]{2}{*}{ Barley } & \multirow[b]{2}{*}{ Control } & \multicolumn{2}{|c|}{$\begin{array}{l}\text { Guar gum } \\
\text { substitution } \\
\text { diets }(\mathrm{g} / \mathrm{kg})\end{array}$} & \multicolumn{2}{|c|}{$\begin{array}{l}\text { Pectin } \\
\text { substitution } \\
\text { diets }(\mathrm{g} / \mathrm{kg})\end{array}$} & \multirow{2}{*}{$\begin{array}{l}\text { SED } \\
25 \mathrm{df}\end{array}$} & \multirow{2}{*}{$\begin{array}{c}\text { Statistical } \\
\text { significance } \\
\text { of difference: } \\
P<\dagger\end{array}$} \\
\hline & & & 10 & 50 & 10 & 50 & & \\
\hline No. of pigs & 6 & 6 & 6 & 6 & 6 & 6 & & \\
\hline \multicolumn{9}{|l|}{ Live wt of pigs $(\mathrm{kg})$} \\
\hline Mean & $27 \cdot 2$ & $28 \cdot 0$ & $26 \cdot 8$ & $23 \cdot 2$ & $28 \cdot 0$ & $28 \cdot 6$ & & \\
\hline $\mathrm{SE}$ & $3 \cdot 3$ & $2 \cdot 7$ & $3 \cdot 5$ & $1 \cdot 4$ & $4 \cdot 6$ & $2 \cdot 3$ & & \\
\hline $\begin{array}{l}\text { Dry matter content of faeces } \\
(\mathrm{g} / \mathrm{kg})\end{array}$ & 280 & 308 & 298 & 319 & 301 & 293 & $9 \cdot 1$ & 0.05 \\
\hline \multicolumn{9}{|l|}{ Rate of passage } \\
\hline \multicolumn{9}{|l|}{$\begin{array}{l}\text { Excretion of chromic oxide } \\
\text { (CR) (h) }\end{array}$} \\
\hline $\begin{array}{l}t_{5} \text { excretion time }(\mathrm{h}) \\
(5 \% \text { excretion of } \mathrm{CR})\end{array}$ & $26 \cdot 8$ & $18 \cdot 7$ & $22 \cdot 0$ & $25 \cdot 9$ & $22 \cdot 2$ & $19 \cdot 9$ & $2 \cdot 93$ & \\
\hline $\begin{array}{l}t_{50} \text { excretion time }(\mathrm{h}) \\
(50 \% \text { excretion of } \mathrm{CR})\end{array}$ & $40 \cdot 9$ & $32 \cdot 3$ & $33 \cdot 5$ & $37 \cdot 2$ & $35 \cdot 5$ & $33 \cdot 3$ & 3.43 & \\
\hline $\begin{array}{l}t_{95} \text { excretion time }(\mathrm{h}) \\
(95 \% \text { excretion of } \mathrm{CR})\end{array}$ & $64 \cdot 7$ & 63.4 & $57 \cdot 3$ & $68 \cdot 0$ & $59 \cdot 3$ & $55 \cdot 6$ & 5.51 & \\
\hline$m \ddagger$ & 5.97 & $4 \cdot 24$ & $5 \cdot 38$ & $5 \cdot 29$ & $5 \cdot 27$ & 4.99 & $0 \cdot 715$ & \\
\hline
\end{tabular}

SED, standard error of difference.

* For details, see Table 1 and p. 396.

$\dagger$ Overall test for differences between diets $P>0.05$ unless otherwise stated.

$\$$ From equation $y=m x+c$ where $y$ is the logarithm of $\mathrm{CR}$ in the faeces: CR in the total gastrointestinal tract, $x$ is the logarithm of time (h) after feeding and $m$ and $c$ are constants.

in the dry matter content of digesta between the $\mathrm{c}$, bran and oatmeal by-product-containing diets at 4 or $7.5 \mathrm{~h}(P>0.05)$.

\section{Expt 4}

Mean gastric emptying rates, $\mathrm{pH}$ and gastric dry matter content values are given in Table 7.

The emptying rate of the $\mathrm{F}$ diets was faster than that of the $\mathrm{C}$ diets but the difference was not significant $(P>0.05)$. The inclusion of guar gum or pectin in the diet significantly increased the rate of emptying compared with the $c$ diet $(P<0.05)$.

At 0.5 and $1 \mathrm{~h}$ the $\mathrm{pH}$ of the digesta for the $\mathrm{F}$ diets was significantly greater than for the $\mathrm{C}$ diets $(P<0.05)$. At 2 and $4 \mathrm{~h}$ the $\mathrm{pH}$ for the $\mathrm{F}$ diets tended to be less than for the $\mathrm{C}$ diets but these differences were not statistically significant. At $0 \cdot 5,1,2$, and $4 \mathrm{~h}$ there were no significant differences between the diets containing guar gum or pectin and diet c. However, at 1 and $4 \mathrm{~h}$ the $\mathrm{pH}$ of digesta from pigs given the diets containing pectin was significantly less than from those consuming the diets containing guar gum. At $7.5 \mathrm{~h}$ the $\mathrm{pH}$ from the $\mathrm{p}$ diets was least and significantly different from diets $\mathrm{Fg}$ and $\mathrm{Cc}(P<0.05)$, but not significantly different from diets $\mathrm{Cg}$ and $\mathrm{Fc}$.

There were no significant differences in digesta dry matter between diets at $0.5 \mathrm{~h}$. At $1 \mathrm{~h}$ the digesta dry matter of the $\mathrm{F}$ diets was significantly less than that of the $\mathrm{C}$ diets $(P<0.01)$, and the digesta dry matter from the diets containing pectin was also significantly less than that of the digesta from the $c$ diets $(P<0.001)$. A comparison of individual means at 2 and $4 \mathrm{~h}$ showed the digesta dry matter from diet $\mathrm{Cc}$ to be significantly greater than for all other diets $(P<0.05)$. At $2 \mathrm{~h}$ the digesta dry matter of diet $\mathrm{Fg}$ was significantly greater than for diet Fp $(P<0.05)$ and at $4 \mathrm{~h}$ the digesta dry matter for diets $\mathrm{Cg}, \mathrm{Fg}$ and $\mathrm{Fp}$ was 
POLYSACCHARIDES AND DIGESTA PASSAGE IN PIGS

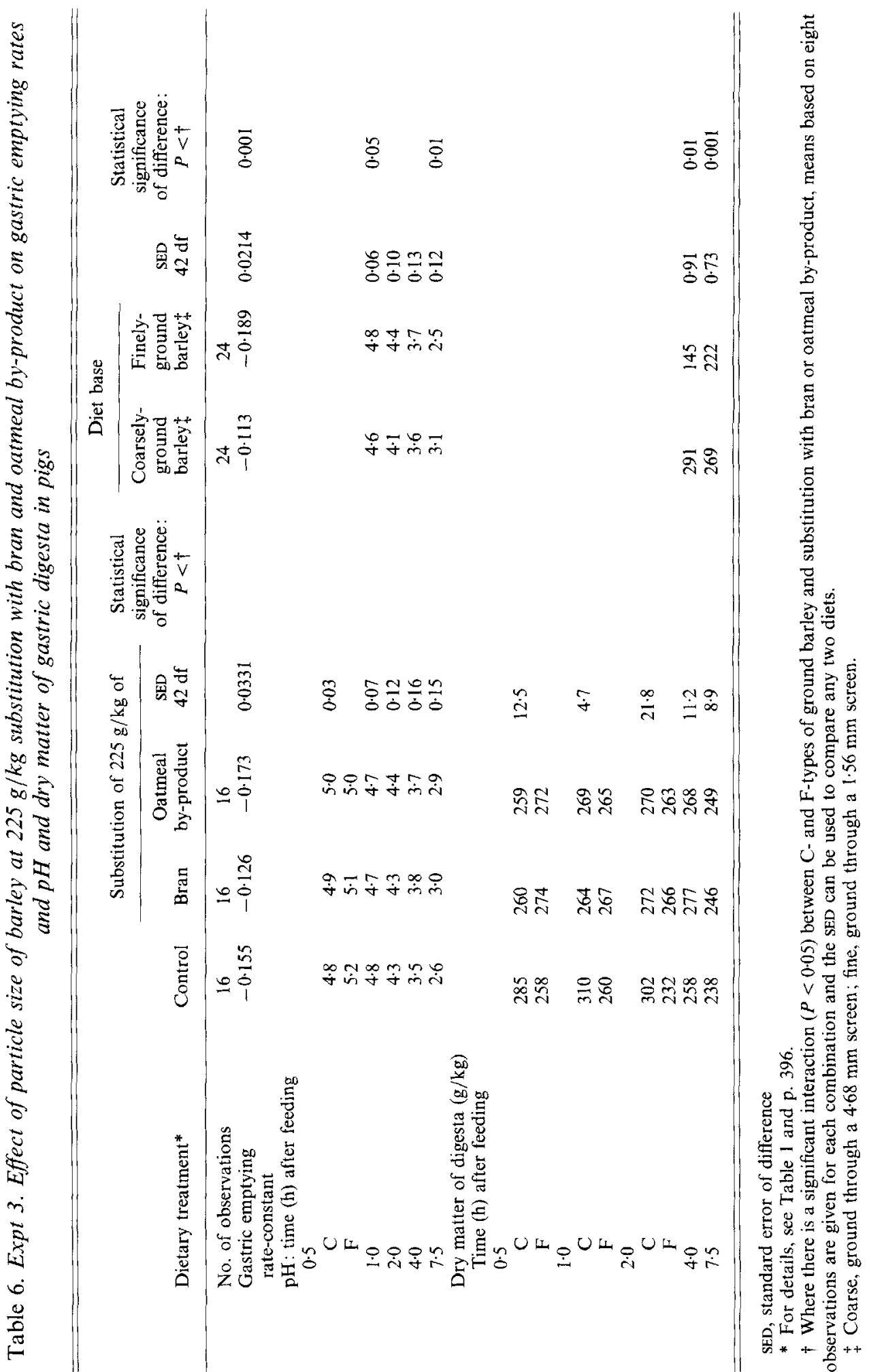




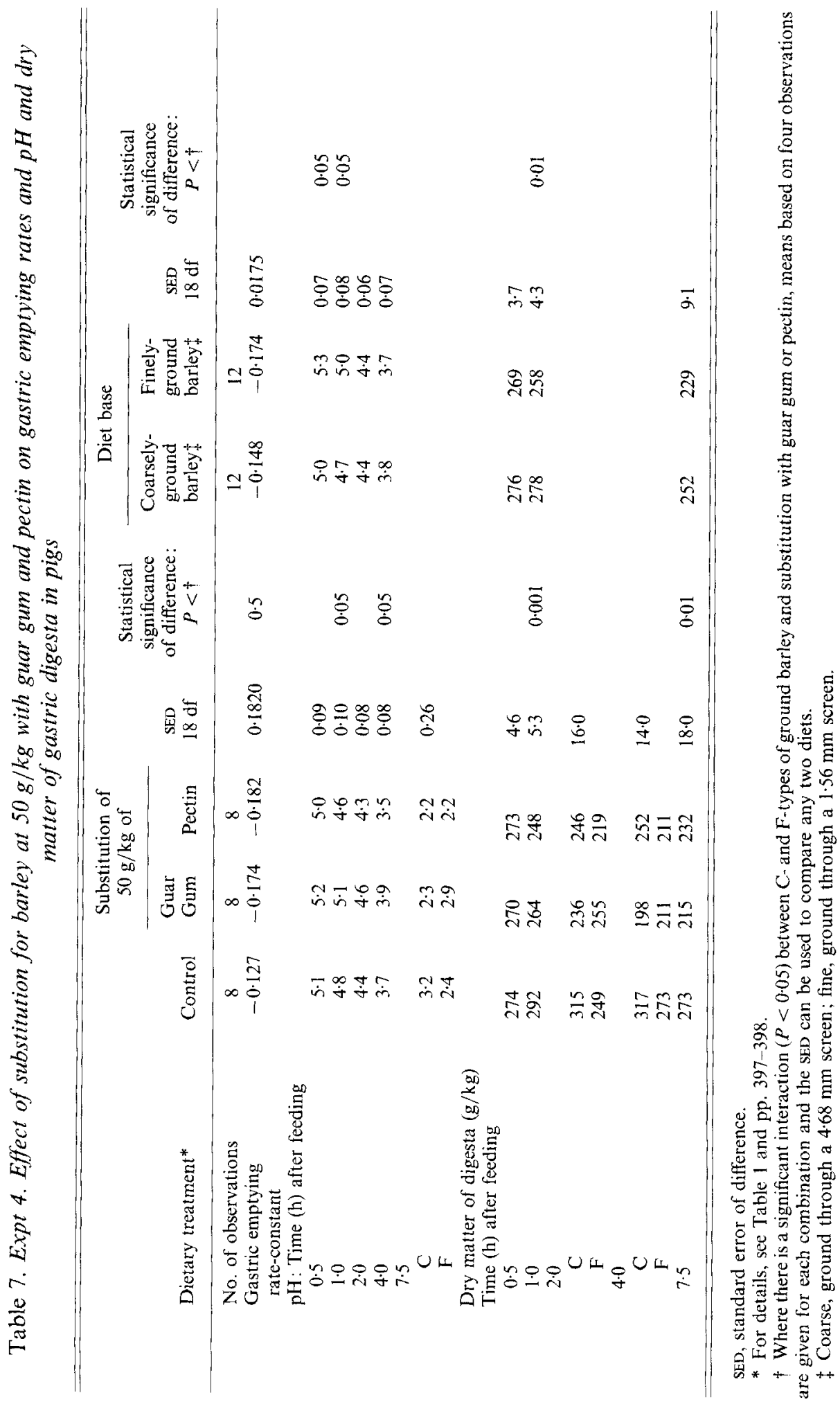


POLYSACCHARIDES AND DIGESTA PASSAGE IN PIGS

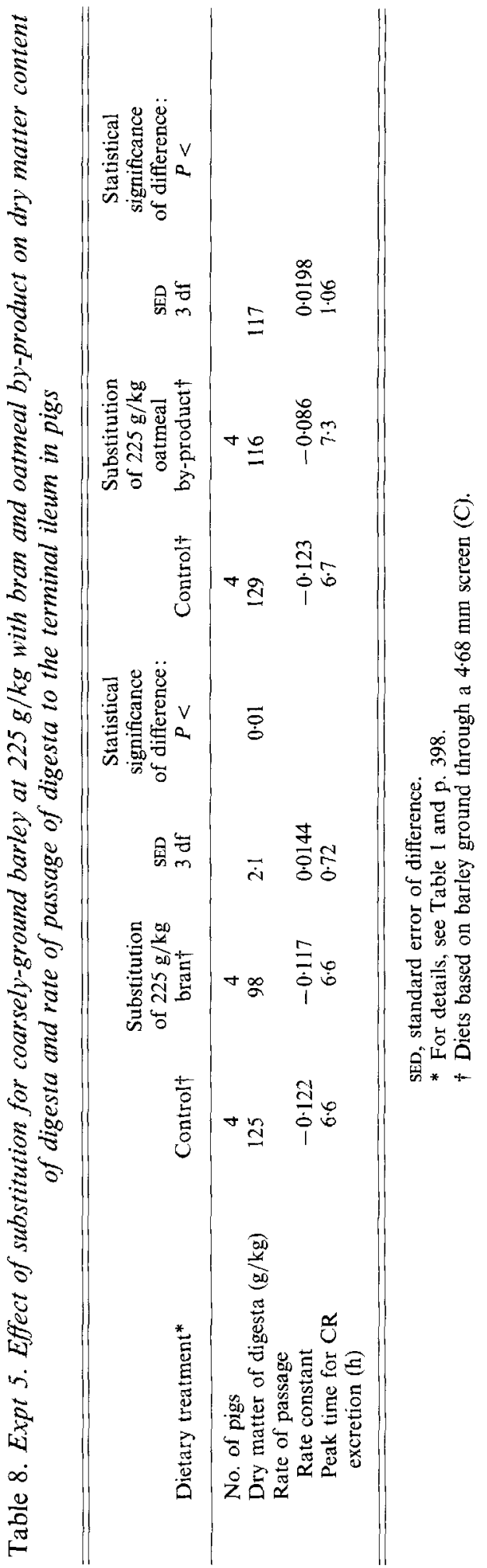


Table 9. Expt 6. Effect of substitution for coarsely-ground barley at $50 \mathrm{~g} / \mathrm{kg}$ with guar gum and pectin on dry matter content and rate of passage of digesta to terminal ileum in pigs

\begin{tabular}{|c|c|c|c|c|c|}
\hline Dietary treatment ${ }^{*}$ & Controlt & $\begin{array}{l}\text { Substitution } \\
\text { of } 50 \mathrm{~g} / \mathrm{kg} \\
\text { of guar gum } \dagger\end{array}$ & $\begin{array}{c}\text { Substitution } \\
\text { of } 50 \mathrm{~g} / \mathrm{kg} \\
\text { of pectint }\end{array}$ & $\begin{array}{l}\text { SED } \\
2 \mathrm{df}\end{array}$ & $\begin{array}{c}\text { Statistical } \\
\text { significance } \\
\text { of difference: } \\
P<\end{array}$ \\
\hline No. of pigs & 3 & 3 & 3 & & \\
\hline $\begin{array}{l}\text { Dry matter of } \\
\text { digesta }(\mathrm{g} / \mathrm{kg})\end{array}$ & 120 & 107 & 124 & $1 \cdot 3$ & $0 \cdot 05$ \\
\hline \multicolumn{6}{|l|}{ Rate of passage } \\
\hline Rate constant & $-0 \cdot 118$ & -0.185 & $-0 \cdot 163$ & 0.0027 & $0 \cdot 001$ \\
\hline $\begin{array}{l}\text { Peak time for } \\
\text { CR excretion }(\mathrm{h})\end{array}$ & $6 \cdot 4$ & $8 \cdot 0$ & $6 \cdot 8$ & 0.59 & \\
\hline
\end{tabular}

SED, standard error of difference.

* For details, see Table 1 and p. 399.

$\uparrow$ Diets based on barley ground through a $4.68 \mathrm{~mm}$ screen $(\mathrm{C})$.

significantly lower than for all other diets $(P<0.05)$. At $7.5 \mathrm{~h}$ there was no significant difference between the $\mathrm{C}$ and $\mathrm{F}$ diets but the guar-gum-containing diets gave significantly lower results than the $\mathrm{c}$ diet $(P<0.01)$.

\section{Expt 5}

Results are presented in Table 8 . The dry matter content of the digesta was significantly lower for the bran-substituted diet compared with the $c$ diet $(P<0.01)$. There were no significant differences between the $c$ - and bran-substituted diets in rate of passage of digesta.

When oatmeal by-product was included in the diet the dry matter content of digesta was not changed significantly. There were no significant differences between either the rate of passage comparing the rate constants, $k_{i}$, or between times of maximum concentration of CR.

\section{Expt 6}

Results are presented in Table 9. The dry matter content of digesta from pigs given diet $\mathrm{Cg}$ was significantly less than that from pigs given diets $\mathrm{Cc}$ or $\mathrm{Cp}(P<0.05)$. Rate of passage of digesta, measured by $k_{i}$ values, from diets $\mathrm{Cg}$ and $\mathrm{Cp}$, was significantly faster than for digesta from diet $\mathrm{Cc}(P<0.001)$. However, there were no significant differences in the times at which the concentration of $\mathrm{CR}$ was maximal $(P>0.05)$.

\section{DISCUSSION}

\section{Total gastrointestinal tract studies}

Overall, the rates of passage of digesta as indicated by $t_{95}$ values were slower than those reported by other workers (e.g. Castle \& Castle, 1956; Fioramonti \& Bueno, 1980). However, substitutions of bran, oatmeal by-product, guar gum and pectin for barley in the diet gave increased rates of passage of digesta through the total gastrointestinal tract, but these were only significant for bran and oatmeal by-product. Although in other work greater effects have been recorded when bulky fibrous foodstuffs such as bran and oatmeal by-product have been added to non-cereal-based diets, the effects with cereal-based diets have been generally equivocal and overall very small (e.g. Canguilhem \& Labie, 1977; Latymer et al. 1985). Nevertheless, the absence of any significant effects in the experiment where guar gum and pectin were substituted agrees with the results of Latymer et al. (1985). 
The water holding properties of dietary fibre, relative to the propensity to form bulky digesta, may have been important in this latter context. Although colonic motility has been shown to be affected by bulky digesta (Kirwan et al. 1974), soluble polysaccharides such as guar gum and pectin have been shown to have higher water-holding capacities than bran, but lower faecal-bulking capacities (Stephen \& Cummings, 1979) and, in consequence, probably less effect on colonic motility and, therefore, on overall rate of passage of digesta. Relative to this, the soluble polysaccharides may be completely fermented in the large intestine (Kertesz, 1940; Bailey et al. 1978), whereas structural polysaccharides may only be partially fermented and therefore exhibit some water-holding capacity and have an effect on faecal dry matter. To some extent the absence of significant effects on faecal dry matter content of substitutions of guar gum and pectin in the control diet supports this possibility but only in the case of oatmeal by-product, and not with bran substitution, did faecal dry matter content increase. In this latter context it is important to remember that the substitution of bran, oatmeal by-product, guar gum and pectin was at the expense of barley in all experiments. Therefore, compared with the control diets in which $125 \mathrm{~g}$ barley $/ \mathrm{kg}$ had been substituted for an identical quantity of, relatively speaking, protein- and mineral-rich components (fish and soya bean meals), barley given alone had significantly lowered faecal dry matter contents, therein indicating that a progressive decrease in water-retention capacity would have been induced in the control diet from the substitution made. On the other hand such changes could not be related consistently to significant differences in rate of passage of digesta.

Therefore, it would seem probable that the rate of passage of digesta through the total gastrointestinal tract in the pig is unlikely to be affected very much by soluble polysaccharides but is increased by some types of fibrous foodstuffs which have lower water-holding capacities, but differing effects on bulking and on colonic motility.

In this particular connection, rate of passage through the lower gut has been shown to be the chief component of the rate of passage in the total gastrointestinal tract (Laplace, 1982). For example, Keys \& De Barthe $(1974 a, b)$ found that proportionately 0.80 of the total time of feed residue retention in the total gastrointestinal tract was spent in the large intestine, whilst Friend et al. (1963) found that at any one time the proportion of the total digesta in the large intestine was between 0.30 and 0.60 . These findings must be placed in perspective relative to the retention times in the total tract of between $35 \mathrm{~h}$ (Castle \& Castle, 1956) and $40.5 \mathrm{~h}$ (Fioramonti \& Bueno, 1980) recorded for cereal-based diets. Although increasing proportions of structural polysaccharides have given generally varying results, there is a suggestion from the collation of results from a number of different experiments of an increased passage rate as found here (Castle \& Castle, 1957; Canguilhem \& Labie, 1977; Fioramonti \& Bueno, 1980; Kass et al. 1980a, b; Kuan et al. 1983). On this basis, depressions in overall apparent digestibility will be related presumably to this, as indicated, for example, in the findings of Just et al. (1984). Using regression analyses on a large body of data they found that the proportions of the total variation in apparent digestibility of gross energy attributable to crude fibre were 0.74 in complete diets and 0.62 in individual foods.

\section{Gastric studies}

Dry matter. The changes in gastric digesta dry matter content after feeding reflect the changing balances brought about between, on the one hand, the addition of liquid from saliva and gastric secretions, and on the other hand, the extent and removal of liquid from the stomach as chyme flowed into the duodenum. The lower dry matter content of digesta from the $\mathrm{F}$ diets is in agreement with the results of many (e.g. Simmonson \& Björklund, 1977). Bran and oatmeal by-product appeared to have had similar effects in decreasing the 
dry matter of digesta when added to the c diets, particularly in the first $2 \mathrm{~h}$ after feeding. When added to the $\mathrm{F}$ diets, dry matter of digesta tended to increase, particularly between 2 and $4 \mathrm{~h}$ after feeding. These results are in agreement with those of Maxwell et al. (1967) and Maxson et al. (1968) where oat hulls were added to the diet (at $250 \mathrm{~g} / \mathrm{kg}$ in the former case). Therefore, irrespective of the physical form of the barley, both polysaccharides clearly influenced the dry matter of digesta in the first $2 \mathrm{~h}$ after feeding. However, at $4 \mathrm{~h}$ and $7.5 \mathrm{~h}$ after feeding the dry matter content of digesta from pigs given the $F$ diets was lower than that of pigs given the $\mathrm{C}$ diets irrespective of the polysaccharide substituted. Up to $2 \mathrm{~h}$ after feeding these results may have reflected the water-holding properties of the fibres of bran and oatmeal by-product. Barley is low in fibre compared with bran and oatmeal byproduct and probably has a lower water-holding capacity. As the liquid phase of digesta has been shown to leave the stomach more rapidly initially than the solid phase, the bran and oatmeal by-product may have associated with some of the liquid phase of the digesta and in so doing may have prevented liquid from leaving the stomach until the fibrous particles of the two fibrous components were emptied themselves. Alternatively, the differences in the dry matter content of digesta may have been due to differences in the volumes of gastric secretions stimulated by each diet.

The effects of substituting either guar gum or pectin for either form of barley was to reduce the dry matter content of digesta, particularly in the $\mathrm{C}$ diets. As both guar gum and pectin are soluble polysaccharides with large affinities for water this reduction in digesta dry matter content may have been a reflection of these properties. According to Stephen \& Cummings (1979) the water-holding capacities of guar gum and pectin, after following an equilibration period of $24 \mathrm{~h}$, are about 21 and $56 \mathrm{~g} / \mathrm{g}$ dry matter respectively. In this experiment measurements were taken during the first $7.5 \mathrm{~h}$ after feeding and therefore the amount of water held was probably less than cited previously, but the progressive increase in the water content of the digesta was apparent when collections of digesta were made over the $7.5 \mathrm{~h}$ period. The decreases in dry matter content of digesta may have resulted from a passive movement of water into the stomach through guar gum and pectin being able to absorb water against the osmotic pressure exerted by the cells of the mucosa. Alternatively, the decrease may have been due to guar gum and pectin either stimulating gastric secretions or preventing water leaving the stomach with digesta, or both.

$p H$. In Expt 1, the $\mathrm{pH}$ of digesta removed from the stomach showed the $\mathrm{F}$ diets having induced a higher $\mathrm{pH}$ initially, a similar $\mathrm{pH}$ at $4 \mathrm{~h}$ after feeding and a more rapid decrease subsequently. Diets $\mathrm{Cbr}$ and Com gave digesta with the highest $\mathrm{pH}$ at $7.5 \mathrm{~h}$ after feeding. The tendency to induce, up to $4 \mathrm{~h}$ after feeding, a higher $\mathrm{pH}$ from feeding $\mathrm{F}$ diets agrees with the findings of Lawrence $(1970 \mathrm{~b})$, and may have resulted from the ease with which the digesta from the $F$ diets mixed with and diluted the acid secretions of the stomach as a whole. In contrast, there may have been a much slower mixing of acid secretions with digesta from the $\mathrm{C}$ diets. After $7.5 \mathrm{~h}$, the amount of dry matter remaining from the $\mathrm{F}$ diets was lower than for pigs on the $\mathrm{C}$ diets. If the rates of acid secretion were similar for all diets, the differential rate of emptying may explain the lower $\mathrm{pH}$ of digesta from the $\mathrm{F}$ diets at this point in time after feeding. The tendency for bran substitution to increase digesta $\mathrm{pH}$ does not agree with the results of Lawrence (1972), but in that latter work a maize-based diet was used, and $\mathrm{pH}$ measurements were made in situ, compared with measurements on extracted samples in the present experiment. Differences in methods of recording $\mathrm{pH}$ must also be considered in the overall interpretation of the $\mathrm{pH}$ results. Diets such as the C-type diets used here, giving digesta with a firm consistency, induce a pH gradient in the stomach with the $\mathrm{pH}$ in the pyloric region being higher than in the fundic region (Maxwell et al. 1970). This may result from a slow mixing of digesta in the centre of the stomach compared with the periphery, which is generally very acidic because of the secretions from the 
mucosal layers (Maxwell et al. 1972). Therefore, for the more solid types of digesta which did not flow freely from the cannula, the $\mathrm{pH}$ would have represented digesta at the pyloric/fundic junction as the sample was taken from the region immediately in front of the cannula. In diets resulting in a more fluid digesta, as in the case of the F-diets in the present experiment, the $\mathrm{pH}$ is likely to be more uniform because of the greater mixing of digesta. Therefore, the $\mathrm{pH}$ of the sampled digesta was likely to have been more representative of the whole digesta in the stomach. In Expt 2, substitution of guar gum or pectin for C- or F-type barley had no significant effect on $\mathrm{pH}$ during the first $4 \mathrm{~h}$ after feeding, but at $7.5 \mathrm{~h}$ after feeding the $\mathrm{pH}$ of the digesta of all diets containing either of the two soluble fibres, except that in which guar gum had been substituted for F-type barley, were significantly lower compared with the $\mathrm{C}$ - and F-type barley control diets. The increase in $\mathrm{pH}$ of digesta from the diets containing either guar gum or pectin was probably a result of the increased rate of emptying of the dry matter of these diets from the stomach. The effect of adding either guar gum or pectin to the $\mathrm{C}$ diet was to give the digesta similar properties to those found in the digesta from the $\mathrm{F}$ diet (especially at 4 and $7.5 \mathrm{~h}$ after feeding): dry matter and $\mathrm{pH}$ were decreased and rate of emptying from the stomach was increased (see below).

Emptying rate. In Expts 3 and 4 the $\mathrm{F}$ diets gave faster emptying rates than the $\mathrm{C}$ diets, but only in the first experiment were differences statistically significant. Substitution of bran or oatmeal by-product had no significant effect on rate of emptying. This is in accord with the overall findings of Rainbird \& Low (1986a). Guar gum and pectin significantly quickened emptying in both the $\mathrm{C}$ and $\mathrm{F}$ diets. In the case of the $\mathrm{C}$ and $\mathrm{F}$ diets the differences in the rate of emptying of dry matter may have resulted from the differences in the fluidity of the food entering the stomach. Although all diets were mixed with the same relative quantities of water, the fluidity of the resultant food varied greatly. The $\mathrm{C}$ diets had a thicker consistency than the $F$ diets and the particles tended to adhere together. In contrast the $\mathrm{F}$ diet was very fluid. The addition of fibre in the form of bran reduced the fluidity of the $\mathrm{F}$ diet but oatmeal by-product, probably because of its finer particle size and lower water-holding capacity, had a much smaller effect. In the case of guar gum and pectin substitutions the decreased digesta dry matter occurred from the presumed absorption of water, especially in the period up to $4 \mathrm{~h}$ after feeding.

During the first $0.5 \mathrm{~h}$ after feeding, the emptying of stomach contents is likely to be rapid due to the large volume and the resulting high intragastric pressure (Laplace $\&$ Tomassone, 1970 ). In this phase the receptive relaxation of the stomach is not rapid enough to accommodate the increase in volume (Laplace, 1982). Relative to this, it is possible that the initial faster emptying rate from the $\mathrm{F}$ diets was greater than for the $\mathrm{C}$ diets because the food particles would have been more readily suspended in the liquid phase. However, after the initial rapid phase of emptying there would have been a feedback from the small intestine as it filled, which would then have slowed the emptying of digesta from the stomach with the result that the rate of emptying was then dependent on the rate of passage of digesta along the small intestine, and also on the rate of digestion of the diet. The significant differences induced in emptying rate by substituting guar gum and pectin could be explained in a similar way. However, at first sight these results differ from those obtained by Rainbird \& Low (1986 b) who found that adding 40 or $60 \mathrm{~g}$ guar gum to each $\mathrm{kg}$ of a semi-purified diet retarded gastric emptying time by $1 \mathrm{~h}$ after feeding $(60 \mathrm{~g} / \mathrm{kg})$ and $4 \mathrm{~h}$ after feeding (40 and $60 \mathrm{~g} / \mathrm{kg}$ ). This difference compared with the results of the present experiment may be more apparent than real because of the different method which Rainbird \& Low (1986 b) used to measure the emptying of dry matter, the limitations of which have been discussed previously. Also, in their experiments the guar gum was substituted in a semi-purified diet. 


\section{Small intestine studies}

The absence of a significant effect of either bran or oatmeal by-product on rate of passage is confirmed by some (Murray et al. 1977; Latymer et al. 1985) but not all (Kass et al. $1980 b$; Den Hartog et al. 1985) other work. Similarly, the significantly-reduced transit time of digesta from the diets with guar gum and pectin substitutions has to be compared with similar effects for pectin but not for methyl cellulose (Murray et al. 1977), and slower transit times for pectin (Latymer et al. 1985). There are several points to consider in interpreting the present results per se and in making comparisons with other published findings. In Expt 6 , although transit time was faster, this may not necessarily have reflected an accelerated passage along the small intestine, as in Expt 4 both guar gum and pectin significantly increased the dry matter gastric emptying rate. Therefore, it is possible that the accelerated passage was influenced by this. In comparisons with other published work, differences in results may reflect differences in such factors as the markers used, the methods used to measure rate of passage, the live weights of the pigs used and the composition and intake of the basal diet in which substitutions of the polysaccharides were made. The method used to assess rate of passage in Expts 5 and 6 was also used by Keys \& De Barthe $(1974 b)$. In their experiments the maximum values with a barley-based diet for concentration of marker and for the rate-constant $k_{i}$ were $9 \cdot 0 / \mathrm{h}$ and $-0.383 / \mathrm{h}$ respectively. The respective values of $6 \cdot 6 / \mathrm{h}$ and $-0 \cdot 122 / \mathrm{h}$ determined for the $\mathrm{c}$ diets in Expt 5 indicate a comparatively slower rate of passage compared with these, but Keys \& De Barthe (1974b) used a lower feeding level and a different marker, thus invalidating comparisons to a certain extent.

From the results of these experiments it would appear unlikely that bran and oatmeal byproduct are able to exert much, if any, effect on apparent digestibility in the small intestine through altering gastric emptying and, either in concert with or without this, transit time of digesta. In the stomach of the pig there may be a small breakdown of cellulose and hemicellulose by fermentation processes (Keys \& De Barthe, 1974a), and in the small intestine the presence of volatile fatty acids indicates that similar processes take place (Friend et al. 1963; Argenzio \& Southworth, 1975). The extent to which such events could have had a causal effect in depressing apparent $\mathrm{N}$-digestibility in some experiments (Keys \& De Barthe, 1974a; Kass et al. $1980 a, b$; Graham et al. 1985), through altering digesta transit, must remain a moot point. However, an examination of these and other results suggests that bran substitution levels have to be in the region of $300 \mathrm{~g} / \mathrm{kg}$ before apparent digestibility of amino acids is depressed, which is above the level of $225 \mathrm{~g} / \mathrm{kg}$ used here. In those experiments where pectin has been found to depress the apparent digestibility of protein and amino acids (e.g. Murray et al. 1977) it is possible that a faster rate of passage of digesta, as found here for diet $\mathrm{Cg}$, could have been involved. Also it is feasible that in the studies of Rainbird et al. (1984) and of Low et al. (1986) where guar gum reduced the absorption of glucose, these results could have been related to shorter retention times in the isolated jejunal loops which were used to facilitate the studies. Results obtained from a small portion of the total small intestine do not necessarily reflect the results which may have been obtained over the entire length of the small intestine had the appropriate studies been made.

\section{CONCLUSIONS}

The results from these experiments indicate that the particle size of the base (barley) of the diet into which either bran or oatmeal by-product were substituted had a bigger effect on gastric emptying rate, $\mathrm{pH}$ and digesta dry matter than did the two foodstuffs themselves, from which only small effects were induced. Gastric emptying rate and rate of passage of digesta along the small intestine were significantly quickened when either guar gum or pectin were substituted for C-type barley in the diet, but bran and oatmeal by-product 
substitutions were without significant effect. Guar gum and pectin tended to decrease the digesta dry matter in the stomach and the former substance significantly decreased the dry matter of digesta in the small intestine. With bran and oatmeal substitutions the only significant effect was of an increase in digesta dry matter concentration in the small intestine.

Relative to studies on the total gut these results indicate; (1) faster rates of passage of digesta through the total gut from bran and oatmeal by-product substitutions are more likely to be related to differences in rates of passage through the large intestine than to differences in gastric-emptying rates or differences in small intestine transit times, or both; (2) the significantly faster gastric emptying rates and small intestine transit times from guar gum and pectin substitutions are likely to be associated with, in view of similarities in transit times through the total gut, delayed passage in the large intestine; (3) differences in digesta dry-matter concentrations in the stomach and small intestine from substitutions of any one of the four polysaccharides bran, oatmeal by-product, guar gum and pectin, are unlikely to be reflected in similar differences, or in any consistent pattern, in the faeces and (4) relative to the changes already mentioned, guar gum and pectin substitutions could have a depressive effect on ileal apparent digestibility but probably not on faecal apparent digestibility, whilst with bran and oatmeal by-product substitutions the major depressive effects on faecal apparent digestibility are likely to occur in the large intestine.

The work was financed by a grant from the Agricultural and Food Research Council. Z.V.P. was in receipt of an Agricultural and Food Research Council Research Assistantship. Technical assistance was provided by Miss L. P. Turtle.

\section{REFERENCES}

Abel, M. \& Buck, W. B. (1967). A technique for gastric cammulation of swine. Cornell Veterinarian 57, 383-389.

Argenzio, R. A. \& Southworth, M. (1975). Sites of organic acid production and absorption in gastrointestinal tract of the pig. American Journal of Physiology 228, 454-460.

Bailey, R. W., Chesson, A. \& Monro, J. (1978). Plant cell wall fractionation and structural analysis. American Journal of Clinical Nutrition 31, S77-S81.

Canguilhem, R. \& Labie, C. (1977). Variations de la durée du transit intestinal chez le porc selon la teneur de la ration en cellulose. (Variation in intestinal transit time in pigs according to the fibre content of the diet.) Revue de Médecine Vétérinaire 128, 1669-1681.

Castle, E. J. \& Castle, M. E. (1956). The rate of passage of food through the alimentary tract of pigs. Journal of Agricultural Science Cambridge 47, 196-203.

Castle, E. J. \& Castle, M. E. (1957). Further studies on the rate of passage of food through the alimentary tract of pigs. Journal of Agricultural Science Cambridge 49, 106-112.

Christian, K. R. \& Coup, M. R. (1954). Measurement of feed intake by grazing cattle and sheep. VI. The determination of chromic oxide in faeces. New Zealand Journal of Science and Technology A. 36, 328.330.

Den Hartog, L. A., Boon, A. J., Huisman, J., Van Leeuwen, P. \& Van Weerden, E. J. (1985). The effect of crude fibre content on the digestibility and the rate of passage in the small and large intestine of pigs. In Proceedings of the 3rd International Seminar on Digestive Physiology in the Pig, pp. 199-202 [A. Just, H. Jørgensen and J. A. Fernandez, editors]. Copenhagen: National Institute of Animal Science.

Diereck, N., Vervaeke, I., Decuypere, J. \& Hendrickx, H. K. (1983). Influence de la nature et du niveau des fibres brutes sur la digestibilité iléale et fécale apparente de la matière seche, des protéines et des acides amines et sur la retention azotée chez les porcs. (Effect of nature and level of crude fibre on apparent ileal and faecal digestibility of dry matter, protein and amino acids and on nitrogen retention in pigs.) Reviews Agriculture 36, 1691-1712.

Fioramonti, J. \& Bueno, L. (1980). Major activity in the large intestine of the pig related to dietary fibre and retention time. British Joumal of Nutrition 43, 155-162.

Friend, D. W., Cunningham, H. M. \& Nicholson, J. W. G. (1963). The production of organic acids in the pig. II. The effect of diet on the levels of volatile fatty acids and lactic acid in sections of the alimentary tract. Canadian Journal of Animal Science 43, 156-168.

Gohl, B., Alden, S., Elwinger, K. \& Thomke, S. (1978). Influence of B glucanase on feeding value of barley for poultry and moisture conient of excreta. British Poultry Science 19, 41-47. 
Gohl, B. \& Gohl, I. (1977). The effect of viscous substances on the transit time of barley digesta in rats. Journal of the Science of Food and Agriculture 28, 911-915.

Graham, H., Hesselman, K. \& Amam, P. (1985). The effect of wheat bran, whole crop peas, and beet pulp on the digestibility of dietary components in a cereal-based pig feed. In Proceedings of the 3rd International Seminar on Digestive Physiology in the Pig, pp. 195-198 [A. Just, H. Jørgensen and J. A. Fernandez, editors]. Copenhagen: National Institute of Animal Science.

Huisman, J., Den Hartog, L. A., Boer, H., Van Weerden, E. J. \& Thielen, W. J. G. (1985). The effect of various carbohydrate sources on the ileal and faecal digestibility of protein and amino acids in pigs. In Proceedings of the 3rd International Seminar on Digestive Physiology in the Pig. pp. 207-210 [A. Just, H. Jørgensen and J. A. Fernandez, editors]. Copenhagen: National Institute of Animal Science.

Just, A., Jørgensen, H. \& Fernandez, J. A. (1984). Prediction of metabolizable energy for pigs on the basis of crude nutrients in the feeds. Livestock Production Science 11, 105-128.

Kass, M. L., Van Soest, P. J. \& Pond, W. G. (1980a). Utilization of dietary fiber from alfalfa by growing swine. 11. Volatile fatty acid concentrations in and disappearance from the gastrointestinal tract. Journal of Animal Science 50, 192-197.

Kass, M. L., Van Soest, P. J., Pond, W. G., Lewis, B. \& McDowell, R. E. (1980 b). Utilization of dietary fiber from alfalfa by growing swine. I. Apparent digestibility of diet components in specific segments of the gastrointestinal tract. Journal of Animal Science 50, 175-191.

Kertesz, Z. I. (1940). Pectic enzymes. V. The fate of pectins in the animal body. Journal of Nutrition 20, $289-296$.

Keys, J. E. \& DeBarthe, J. V. (1974a). Cellulose and hemicellulose digestibility in the stomach, small intestine and large intestine of swine. Joumal of Animal Science 39, 53-56.

Keys, J. E. \& DeBarthe, J. V. (1974b). Site and extent of carbohydrate, dry matter, energy and protein digestion and the rate of passage of grain diets in swine. Journal of Animal Science 39, 57-62.

Kirwan, W. O., Smith, A. N., McConnell, A. A., Mitchell, W. D. \& Eastwood, M. A. (1974). Action of different bran preparations on colonic function. British Medical Journal 4, 187-189.

Kuan, K. K., Stanogias, G. \& Dunkin, A. C. (1983). The effect of proportion of cell-wall material from lucerne leaf meal on apparent digestibility, rate of passage and gut characteristic in pigs. Animal Production 36, 201-209.

Laplace, J. P. (198I). The transit of digesta in different parts of the digestive tract of the pig. In Nutrition in Health and Disease and International Developments, pp. 847-872 [A. E. Harper and G. K. Davis editors]. New York: Alan Liss.

Laplace, J. P. (1982). Fonction de l'estomac chez le porc: revision de concepts usuels sue son rôle dans la digestion et la mécanique de son évacuation. Les Colloques de L'Institut National de la Recherche Agronomique no. 12 , pp 29-44. Paris: Institut National de la Recherche Agronomique.

Laplace, J. P. \& Tomassone, R. (1970). Évacuation gastro-duodenale chez le porc. Fistulation chronique par voie thoracique extra-pleurale: recherche d'une technique d'analyse mathématique de l'évacuation. (Gastroduodenal emptying in the pig. Chronic fistulation through extra pleural thoracic pathway: study of a technique for mathematical analysis of emptying.) Annales de zootechnie 19, 303-332.

Latymer, E. A., Low, A. G. \& Woodley, S. C. (1985). The effect of dietary fibre on the rate of passage through different sections of the gut in pigs. In Proceedings of the 3rd International Seminar on Digestive Physiology in the Pig, pp 215-218 [A. Just, H. Jørgensen and J. A. Fernandez, editors]. Copenhagen: National Institute of Animal Science.

Lawes Agricultural Trust (1982). GENSTAT V, Mark 4.04B. Harpenden: Rothampstead Experimental Station.

Lawrence, T. L. J. $(1970 \mathrm{a})$. Some effects of including differently processed barley in the diet of the growing pig. 1. Growth rate, food conversion efficiency, digestibility and rate of passage through the gut. Animal Production 12, $139-150$.

Lawrence, T. L. J. (1970 b). Some effects of including differently processed barley in the diet of the growing pig. 2. In vivo gastric $\mathrm{pH}$ changes. Animal Production 12, 151-163.

Lawrence, T. L. J. (1972). The effect of certain dietary factors on in vivo $\mathrm{pH}$ changes and pepsin activity in the stomach of the growing pig. British Veterinary Journal 128, 402-411.

Livingstone, R. M. (1980). Some dietary factors affecting digestive efficiency and sites of nutrient absorption in the pig. PhD Thesis, University of Aberdeen.

Low, A. G., Zebrowska, T., Heppell, L. M. J. \& Smith, H. A. (1986). Influence of wheat bran, cellulose, pectin and low or high viscosity guar gum on glucose and water absorption from pig jejunum. Proceedings of the Nutrition Society 45, 55A.

Maxson, D. W., Stanley, G. R., Perry, T. W., Pickett, R. A. \& Curtin, T. M. (1968). Influence of various ratios of raw and gelatinized corn, oats, oat components and sand on the incidence of esophogogastric lesions in swine. Journal of Animal Science 27, 1006-1010.

Maxwell, C. V., Reese, N. A., Muggenburg, B. A., Reimann, E. M., Kowalyczyk, T., Grummer, R. H. \& Hoekstra, W. G. (1967). Effect of oat hulls and other oat fractions on the development of gastric ulcers in swine. Journal of Animal Science 26, 1312-1318.

Maxwell, C. V., Reimann, E. M., Hoekstra, W. G., Kowalyczyk, T., Benevenga, N. J. \& Grummer, R. H. (1970). Effect of dietary particle size on lesion development and on the contents of various regions of the swine stomach. Journal of Animal Science 30, 911-922. 
Maxwell, C. V., Reimann, E. M., Hoekstra, W. G., Kowalyczyk, T., Benevenga, N. J. \& Grummer, R. H. (1972). Use of tritiated water to assess, in vivo, the effect of dietary particle size on the mixing of stomach contents of swine. Journal of Animal Science 34, 212-216.

Murray, A. G., Fuller, M. F. \& Pirie, A. R. (1977). The effect of fibre in the form of various polysaccharides on the apparent digestibility of protein in the pig. Animal Production 24, 139.

Potkins, Z. V. (1986). Dietary manipulation relative to gastro-intestinal disorders and nutrient utilization in the growing pig. PhD Thesis, University of Liverpool.

Rainbird, A. L. (1986). Effect of guar gum on gastric emptying of test meals of varying energy content in growing pigs. British Journal of Nutrition 55, 99-109.

Rainbird, A. L. \& Low, A. G. (1986a). Effect of various types of dietary fibre on gastric emptying in growing pigs. British Journal of Nutrition 55, 111-121.

Rainbird, A. L. \& Low, A. G. (1986b). Effect of guar gum on gastric emptying in growing pigs. British Journal of Nutrition 55, 87-98.

Rainbird, A. L., Low, A. G. \& Zebrowska, T. (1984). Effect of guar gum on glucose and water absorption from isolated loops of jejunum of growing pigs. British Journal of Nutrition 52, 489-498.

Rainbird, A. L. \& Sissons, J. W. (1985). Effect of gastric cannulation on gastrointestinal motility in the pig. In Proceedings of the 3rd International Seminar on Digestive Physiology in the Pig, pp. 69-71 [A. Just, H. Jørgensen and J. Fernandez, editors]. Copenhagen: National Institute of Animal Science.

Rowan, T. G. (1983). Studies on the utilization of low glucosinolate rapeseed meals in the growing pig. PhD Thesis, University of Liverpool.

Simonsson, A. \& Björklund, N.-E. (1977). Effects of Grist Size of Barley on Performance and Incidence of Oesophagogastric Lesions in Growing Pigs, p. 20. Uppsala: Sveriges Lantbruksuniversitat.

Stephen, A. M. \& Cummings, J. H. (1979). Water-holding by dietary fibre in vitro and its relationship to faecal output in man. Gut 20, 722-729. 